\title{
Enhancing the thermostability and activity of uronate dehydrogenase from Agrobacterium tumefaciens LBA4404 by semi-rational engineering
}

\author{
Hui-Hui Su ${ }^{1 \dagger}$, Fei Peng ${ }^{1 \dagger}$, Pei Xu' ${ }^{1}$, Xiao-Ling Wu ${ }^{1}$, Min-Hua Zong ${ }^{1}$, Ji-Guo Yang ${ }^{2}$ and Wen-Yong Lou ${ }^{1 *}$ (e)
}

\begin{abstract}
Background: Glucaric acid, one of the aldaric acids, has been declared a "top value-added chemical from biomass", and is especially important in the food and pharmaceutical industries. Biocatalytic production of glucaric acid from glucuronic acid is more environmentally friendly, efficient and economical than chemical synthesis. Uronate dehydrogenases (UDHs) are the key enzymes for the preparation of glucaric acid in this way, but the poor thermostability and low activity of UDH limit its industrial application. Therefore, improving the thermostability and activity of UDH, for example by semi-rational design, is a major research goal.
\end{abstract}

Results: In the present work, three UDHs were obtained from different Agrobacterium tumefaciens strains. The three UDHs have an approximate molecular weight of $32 \mathrm{kDa}$ and all contain typically conserved UDH motifs. All three UDHs showed optimal activity within a $\mathrm{pH}$ range of $6.0-8.5$ and at a temperature of $30^{\circ} \mathrm{C}$, but the UDH from A. tumefaciens (At) LBA4404 had a better catalytic efficiency than the other two UDHs ( $800 \mathrm{vs} 600$ and $530 \mathrm{~s}^{-1} \mathrm{mM}^{-1}$ ). To further boost the catalytic performance of the UDH from AtLBA4404, site-directed mutagenesis based on semi-rational design was carried out. An A39P/H99Y/H234K triple mutant showed a 400 -fold improvement in half-life at $59^{\circ} \mathrm{C}$, a $5^{\circ} \mathrm{C}$ improvement in $\mathrm{T}_{50}^{10}$ value and a 2.5 -fold improvement in specific activity at $30^{\circ} \mathrm{C}$ compared to wild-type UDH.

Conclusions: In this study, we successfully obtained a triple mutant (A39P/H99Y/H234K) with simultaneously enhanced activity and thermostability, which provides a novel alternative for the industrial production of glucaric acid from glucuronic acid.

Keywords: Uronate dehydrogenase, Semi-rational engineering, Biocatalysis, Glucuronic acid, Glucaric acid

\section{Background}

Uronate dehydrogenase (EC 1.1.1.203, UDH), an $\mathrm{NAD}^{+}$-like oxidoreductase, can convert uronic acids [e.g., glucuronic acid (GlcA)] into aldaric acids [e.g., glucaric acid (GA)] (Fig. 1). UDH was first found in Agrobacterium tumefaciens strain C58 and Pseudomonas syringae pv. tomato strain DC3000 (Zajic et al. 1959; Wagner

\footnotetext{
${ }^{*}$ Correspondence: wylou@scut.edu.cn

${ }^{+}$Hui-Hui Su and Fei Peng contributed equally to this work

${ }^{1}$ Laboratory of Applied Biocatalysis, School of Food Science and Engineering, South China University of Technology,

Guangzhou 510640, People's Republic of China

Full list of author information is available at the end of the article
}

and Hollmann 1976). Subsequently, UDHs were also cloned and characterized from other organisms, including Pseudomonas putida KT2440, Fulvimarina pelagi HTCC2506, Oceanicola granulosus DSM15982, Streptomyces viridochromeogenes DSM40736, Polaromonas naphthalenivoransCJ2 and Thermo bispora DSM43833 (Moon et al. 2009; Pick et al. 2015; Wagschal et al. 2015; Li et al. 2018).

Recently, UDH has attracted considerable attention as the key enzyme for GA and galactarate production from uronic acids. GA was identified as a "top value-added chemical from biomass" by the US Department of Energy in 2004 (Werpy et al. 2004) and shows considerable 
potential in the food and pharmaceutical industries, with applications as a food additive, dietary supplement, therapeutic medicine, agent builder and polyamide derivative (Dwivedi et al. 1990; Bespalov and Aleksandrov 2012; Walaszek 1990; Zółtaszek et al. 2008; Morton and Kiely 2000). Of all the characterized UDHs, the enzyme from A. tumefaciens strain C58 shows the highest catalytic efficiency $\left(829 \mathrm{~s}^{-1} \mathrm{mM}^{-1}\right)$ with GlcA as substrate. However, its $\mathrm{T}_{50}^{50}$ value is only $37^{\circ} \mathrm{C}$ (Pick et al. 2015). Subsequently, Roth et al. achieved a more thermostable triple variant with a $\mathrm{T}_{50}^{15}$ value of $62^{\circ} \mathrm{C}$ and a $\Delta \Delta \mathrm{G}_{\mathrm{U}}$ of $2.3 \mathrm{~kJ} / \mathrm{mol} \mathrm{com-}$ pared to wild-type (Roth et al. 2017). However, this variant still does not meet the requirements of industry.

In line with the hypothesis that conformational changes in the catalytic center during heat treatment affect enzyme activity, researchers have attempted to improve the thermostability of various enzymes by increasing the stability of the catalytic center using a structure-guided enzyme engineering approach (Tanner et al. 1996; Blair et al. 2007; Etzl et al. 2018; Zhang et al. 2016). Thus, the thermostability of $\alpha$-keto acid decarboxylase, measured as the temperature at which $50 \%$ activity remains after a 1 -h incubation, $\mathrm{T}_{50}^{1 \mathrm{~h}}$, improved by $3.3^{\circ} \mathrm{C}$ compared to wild-type after structure-guided engineering of the catalytic center (Sutiono et al. 2018). Surface engineering can also increase enzyme thermostability by altering hydrogen bonds, salt bridges and hydrophobic interactions (Alponti et al. 2016; Eijsink et al. 2004; Yang et al. 2007). For example, the half-life and $T_{\mathrm{m}}$ of alkaline $\alpha$-amylase from Alkalimonas amylolytica were raised by 6.4-fold and $5.4{ }^{\circ} \mathrm{C}$, respectively, after introducing multiple arginines on the protein surface (Deng et al. 2014).

In this work, the enzyme characteristics of three UDHs from three $A$. tumefaciens strains were investigated. We attempted to enhance the thermostability and activity of one particular example (AtLBA4404 UDH) by generating small and smart enzyme libraries through semi-rational engineering. Analysis of the structure of the most promising variants showed that the mutated positions were mainly located in the flexible loop near the catalytic center.

\section{Materials and methods}

\section{Bacterial strains and plasmids}

Three A. tumefaciens strains, A. tumefaciens LBA4404 (AtLBA4404), A. tumefaciens GV3101 (AtGV3101) and A. tumefaciens EHA105 (AtEHA105), were used as genomic templates. The above strains were donated by Prof. Li from Guangdong Academy of Agricultural Sciences (Guangdong, China). The engineered Escherichia coli strains containing the target genes were cultured in Luria-Bertani (LB) broth with antibiotics $(50 \mu \mathrm{g} /$ $\mathrm{ml}$ kanamycin) at $37^{\circ} \mathrm{C}$. E. coli DH5 $\alpha$ (Trans Gen Biotech, China) and E. coli BL21 (DE3) (Trans Gen Biotech, China) were used as the cloning host and expression host, respectively. The plasmid pET-28a(+) (Jierui, China) was employed as the template for overexpression of the UDHs.

\section{Expression and purification of recombinant proteins}

The preparation of genomic DNA and general cloning steps were performed as previously described (Zhu et al. 2014). We confirmed that the candidate genes of the three A. tumefaciens strains contained conserved UDH domain sequences by PCR and sequencing. The primers used to amplify the conserved domain sequences from their genomic DNA are shown in Additional file 1: Table S1. The three target UDH genes were digested with restriction enzymes HindIII and XhoI and then ligated into the corresponding restriction sites of pET-28a $(+)$. The resulting constructs (pLBA-UDH, pGV-UDH and pEHA-UDH) were transformed into E. coli DH5 $\alpha$ and positive cells were confirmed by gene sequencing.

Escherichia coli BL21 (DE3) carrying recombinant plasmids was first incubated overnight in LB medium containing kanamycin $(50 \mu \mathrm{g} / \mathrm{ml})$ and shaken at $37{ }^{\circ} \mathrm{C}$ and $200 \mathrm{rpm}$. Then, $1 \%(\mathrm{v} / \mathrm{v})$ of these cultures were used to seed fresh LB broth medium with kanamycin $(50 \mu \mathrm{g} /$ $\mathrm{ml}$ ) and cultured at $37{ }^{\circ} \mathrm{C}$ and $200 \mathrm{rpm}$. When the $\mathrm{OD}_{600}$ reached $0.6-0.8$, isopropyl $\beta$-D-1-thiogalactopyranoside (IPTG, final concentration $0.2 \mathrm{mM}$ ) was added to trigger the expression of the target genes. After expression at $20{ }^{\circ} \mathrm{C}$ for $20-24 \mathrm{~h}$, the cells were harvested at $8000 \times g$ for

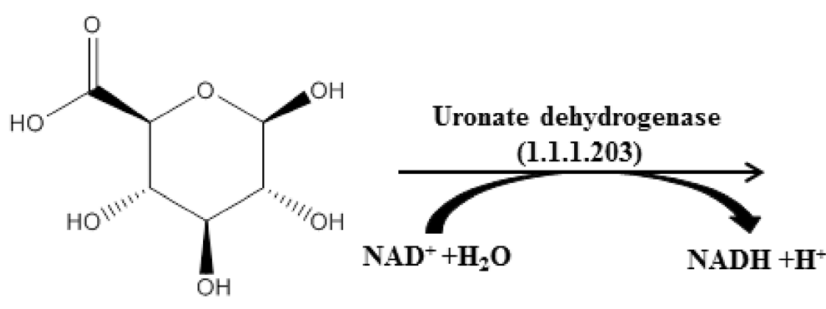

D-glucuronic acid

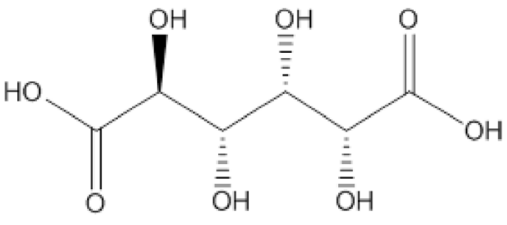

D-glucaric acid

Fig. 1 Uronate dehydrogenase catalyzes a dehydrogenation reaction at C1, 6 position of glucuronic acid 
$10 \mathrm{~min}$ and resuspended in lysis buffer $\left(20 \mathrm{mM} \mathrm{Na}_{2} \mathrm{HPO}_{4}\right.$ (pH 7.4), $500 \mathrm{mM} \mathrm{NaCl}$ and $20 \mathrm{mM}$ imidazole). Next, cells were sonicated and the cell homogenates were centrifuged. The supernatants were filtered and loaded onto a nickel column (Ni-NTA, Bio-Rad laboratories, Hercules, CA) using the manufacturer's instructions for purification.

\section{Enzyme activity assay}

UDH activity was measured by determining NADH generation at $340 \mathrm{~nm}$ and $30{ }^{\circ} \mathrm{C}$ in a potassium phosphate buffer (KPi) reaction system $(50 \mathrm{mM}, \mathrm{pH} 8.0)$ containing GlcA $(5 \mathrm{mM})$, galacturonic acid $(5 \mathrm{mM})$ and $\mathrm{NAD}^{+}(2 \mathrm{mM})$. One unit of UDH activity was defined as the amount of UDH which generated $1 \mu \mathrm{mol}$ NADH in $1 \mathrm{~min}$. Protein concentration was measured using the Bradford method (Kruger 1988).

The thermostability of UDH and variants was evaluated by the parameters half-life $\left(t_{1 / 2}\right)$ and $\mathrm{T}_{50}^{10}: t_{1 / 2}$ was determined by measuring the residual activity of the enzymes at $59^{\circ} \mathrm{C}$ and $\mathrm{pH}$ 8.0. $\mathrm{T}_{50}^{10}$ was defined as the temperature $\left(50-65{ }^{\circ} \mathrm{C}\right)$ at which $50 \%$ of the enzyme $(0.05 \mathrm{mg} / \mathrm{ml})$ was inactivated in $10 \mathrm{~min}$.

\section{Characterization of the UDHs}

The optimal $\mathrm{pH}$ values of the three UDHs were evaluated in the following buffer systems: citric acid-sodium citrate ( $\mathrm{pH} 4.0-7.0,50 \mathrm{mM}), \mathrm{KPi}(\mathrm{pH} 7.0-9.0,50 \mathrm{mM})$ and glycine- $\mathrm{NaOH}$ (pH 9.0-11.0, $50 \mathrm{mM}$ ). The optimal temperatures of the UDHs were also assayed in $\mathrm{KPi}$ buffer (50 mM, pH 8.0) with a temperature range of $4{ }^{\circ} \mathrm{C}-50{ }^{\circ} \mathrm{C}$ for wild-type UDH. UDH thermostability was assessed after incubation at temperatures in the range $4-50{ }^{\circ} \mathrm{C}$ for $3 \mathrm{~h}$.

The effect of various metal ions, including $\mathrm{FeCl}_{2}, \mathrm{FeCl}_{3}$, $\mathrm{MgCl}_{2}, \mathrm{CoCl}_{2}, \mathrm{ZnCl}_{2}$ and $\mathrm{CuCl}_{2}(2 \mathrm{mM})$, on UDH activity was investigated. The effect of chemical regents Triton X-100, ethylene diamine tetra-acetic acid (EDTA), sodium dodecyl sulfate and urea on UDH activity was also tested.

The enzyme activity in the additive-free buffer was used as $100 \%$ for comparison purposes.

The kinetic parameters of the UDHs were measured using glucuronate or galacturonate as substrate at $0-10 \mathrm{mM}$ in $\mathrm{KPi}$ buffer containing $1.2 \mathrm{mM} \mathrm{NAD}^{+}$ (50 mM, pH 8.0). Similarly, kinetic analysis was performed using $\mathrm{NAD}^{+}$in the concentration range $0-1.5 \mathrm{mM}$ in KPi buffer containing $10 \mathrm{mM}$ glucuronate (50 mM, pH 8.0). The initial rate of the same enzyme concentration was evaluated for a series of different substrates. Nonlinear curve fitting was performed according to the Michaelis-Menten equation using Origin 8.0.

\section{Site-directed mutagenesis of $A$. tumefaciens LBA4404}

The UDH from AtLBA4404 was selected for further molecular modification because it showed the highest $k_{\text {cat }} / K_{m}\left(800 \mathrm{~s}^{-1} \mathrm{mM}^{-1}\right)$ of the three UDHs. A model of the UDH from AtLBA4404 was constructed by homology modeling using Swiss-model (http://swissmodel.expas y.org/) (Biasini et al. 2014) with the crystal structure of UDH from AtC58 (PDB code 3RFT) as the template (Parkkinen et al. 2011). Deep View (http://spdbv.wital-it. $\mathrm{ch} /$ ) was used to evaluate which of the mutated amino acid positions were located on the protein surface and a default value of $30 \%$ solvent exposure was chosen.

To generate a mutant library, we performed the polymerase chain reaction (PCR) using pET28a-AtLBA4404UDH as the template and the degenerate codon NNK (Additional file 1: Table S1). E. coli BL21 (DE3) containing the mutant clones was grown on LB agar plates with $50 \mu \mathrm{g} / \mathrm{ml}$ kanamycin for $16 \mathrm{~h}$. As single colony was picked and cultured in 96-deep-well plates containing medium with $100 \mu \mathrm{g} / \mathrm{ml}$ kanamycin and $0.05 \mathrm{M}$ IPTG for $20 \mathrm{~h}$ at $30^{\circ} \mathrm{C}$. A culture volume of $100 \mu \mathrm{l}$ was centrifuged (5000 rpm for $10 \mathrm{~min}$ at $4{ }^{\circ} \mathrm{C}$ ), and the pellets were stored at $-80{ }^{\circ} \mathrm{C}$ for $4 \mathrm{~h}$. Next, $50 \mu \mathrm{l}$ lysis buffer $(50 \mathrm{mM} \mathrm{KPi}$ $\mathrm{pH}$ 8.0) was added at $37^{\circ} \mathrm{C}$ for $1 \mathrm{~h}$, and then centrifuged (1000 rpm for $5 \mathrm{~min}$ at $4{ }^{\circ} \mathrm{C}$ ). Subsequently, $50 \mu \mathrm{l}$ supernatant was incubated in a PCR thermocycler at $30-65^{\circ} \mathrm{C}$ for $10 \mathrm{~min}$, then mixed with the substrate reaction solution (50 $\mathrm{mM} \mathrm{KPi} \mathrm{pH} \mathrm{8.0,} 1 \mathrm{mM} \mathrm{MgCl}$ and $10 \mathrm{mM} \mathrm{GlcA}$ ), and finally the residual activity was determined according to "Enzyme activity assay" section.

\section{Product analysis by NMR}

The synthesis of GA from GlcA by UDH was carried out in a $25 \mathrm{ml}$ reaction system with $5 \mathrm{mg} \mathrm{UDH}$, KPi buffer (50 mM, pH 8.0), $2 \mathrm{mM} \mathrm{NAD}^{+}$and $10 \mathrm{mM}$ GlcA. The reaction was incubated for $30-60 \mathrm{~min}$ at $30{ }^{\circ} \mathrm{C}$ and then stopped with acetonitrile (1:10). The product was dissolved in $\mathrm{D}_{2} \mathrm{O}$ for NMR analysis. 1H-NMR spectra were recorded on a Bruker $600 \mathrm{MHz}$ instrument (Bruker Corporation, Fallanden, Switzerland). The spectra were obtained at $30^{\circ} \mathrm{C}$, a delay time of $10 \mathrm{~s}$, and a delay time of $10 \mathrm{~s}$, and an acquisition time of $2 \mathrm{~s}$.

\section{Bioconversion of GlcA with purified UDH enzyme}

The reaction system was carried out in $100 \mathrm{ml}$ consisting of $50 \mathrm{mM} \mathrm{KPi} \mathrm{(pH} \mathrm{8.0),} 5 \mathrm{mg} / \mathrm{l}$ purified UDH, $10 \mathrm{mM}$ $\mathrm{NAD}^{+}, 30 \mathrm{mM}$ GlcA at $30{ }^{\circ} \mathrm{C}$ for wild-type and H99Y/ $\mathrm{H} 234 \mathrm{~K}$, or at $37^{\circ} \mathrm{C}$ for A39P/H99Y/H234K, and stopped by cooling on ice. GA production was stoichiometric with NADH formation, which was monitored in a spectrophotometer by absorbance at $340 \mathrm{~nm}$ and $30^{\circ} \mathrm{C}$. The yields of GA were determined using a high-performance liquid chromatograph equipped with Waters 1525 refractive 
index detectors (Waters, USA), and an Aminex HPX-87H column $(300 \mathrm{~mm} \times 7.8 \mathrm{~mm}$, Bio-Rad Laboratories, Hercules, $\mathrm{CA}$ ). The mobile phase was $5 \mathrm{mM} \mathrm{H}_{2} \mathrm{SO}_{4}$, and the column was eluted at $65{ }^{\circ} \mathrm{C}$ at a flow rate of $0.5 \mathrm{ml} / \mathrm{min}$. The samples were withdrawn at different reaction points to determine the yield of product. All experiments were performed in triplicate.

\section{Statistical analysis}

Data were obtained at least in triple and expressed as mean \pm standard deviation (SD). To test for statistically significant differences between conditions, an unpaired two-tailed Student's $t$ test was applied assuming equal variance. The level of significance is indicated in figures by the following: $p<0.01, p<0.001$.

\section{Results}

\section{Characterization of three UDH genes and their cognate enzymes}

Cloning of the UDH genes from A. tumefaciens strains allowed us to analyze the predicted amino acid sequences of their respective enzymes. All three proteins contained characteristically conserved UDH motifs, such as GxxGxxG and YxxxK (Thomas et al. 2002; Hoffmann et al. 2007; Yoon et al. 2009). In addition, the three UDHs were very similar to that of $A$. tumefaciens $\mathrm{C} 58$, with a sequence identity of $89 \%, 98 \%$ and $98 \%$ for $A$. tumefaciens LBA4404, A. tumefaciens GV3101 and A. tumefaciens EHA105, respectively (Additional file 1: Fig. S1). Details of the three genes have been deposited at NCBI, with accession numbers MF663795 (A. tumefaciens LBA4404), MF663796 (A. tumefaciens GV3101) and MF663797 (A. tumefaciens EHA105).

We next prepared recombinant versions of each UDH. SDS-PAGE suggested that the molecular mass of all three enzymes was $32 \mathrm{kDa}$ (Additional file 1: Fig. S2), consistent with their theoretical value as well as a previous report (Yoon et al. 2009). Purification and yield details are provided in Additional file 1: Table S2. The purified wild-type UDHs displayed the highest catalytic activity at $30{ }^{\circ} \mathrm{C}$, but demonstrated thermal instability above $30{ }^{\circ} \mathrm{C}$ (Additional file 1: Fig. S3a, b). This limitation hinders biocatalytic applications of wide-type UDHs in industry. All three UDHs performed with relatively high enzyme activity in the $\mathrm{pH}$ range $6.0-8.5$, with optimal activity at pH 8.0 (Additional file 1: Fig. S3c). We also measured the effect of metal ions on enzyme activity (Additional file 1: Table S3) and determined their kinetic parameters (Additional file 1: Table S4). No significant differences in the activity and thermostability of the UDHs from the three A. tumefaciens strains were observed. However, the UDH from $A$. tumefaciens LBA4404 showed higher kinetic efficiency $\left(k_{\text {cat }} / K_{m}: 800 \mathrm{~s}^{-1} \mathrm{mM}^{-1}\right)$ for glucuronate than the enzymes from A. tumefaciens GV3101 $\left(k_{\mathrm{cat}} / K_{m}: 600 \mathrm{~s}^{-1}\right.$ $\left.\mathrm{mM}^{-1}\right)$ or A.tumefaciens EHA105 $\left(k_{\mathrm{cat}} / K_{m}: 530 \mathrm{~s}^{-1}\right.$ $\mathrm{mM}^{-1}$ ). Therefore, the UDH derived from $A$. tumefaciens LBA 4404 was selected for further study.

\section{Identification of target residues for mutagenesis and construction of mutant}

To attempt to improve the thermostability of the UDH from $A$. tumefaciens LBA4404, we adopted a structureguided enzyme engineering strategy, which involves mutation of key sites in the protein sequence. Initially, therefore, we constructed a homology model of UDH using Swissmodel (https://swissmodel.expasy.org/) with the UDH from $A$. tumefaciens C58 (PDB code 3RFT) as the template) (Parkkinen et al. 2011). This homology model showed that 93.12\% of the residues have an averaged 3D-1D score $\geq 0.2$ (Indeed, at least $80 \%$ of the amino acids scored $\geq 0.2$ in the 3D-1D profile (Additional file 1: Fig. S4).

Identification of amino acid positions for mutation in At58 UDH was based on the structure-guided enzyme engineering and a previously report (Roth et al. 2017) to select target residues in the UDH from AtLBA4404. Five residues (L36, A39, E79, H99 and H234) in the UDH amino acid sequence were identified as candidates and were altered by site-directed saturation mutagenesis (Fig. 2). We found that some mutations in sites A39, H99 and $\mathrm{H} 234$ had a positive effect on thermostability and enzyme activity (Table 1).

To check the thermostability of the UDH mutants, enzyme solutions from engineered $E$. coli strains' cellfree supernatants were incubated in 96-well PCR plates at $58{ }^{\circ} \mathrm{C}$ for $10 \mathrm{~min}$. Subsequently, the residual activity of the UDH mutants was determined. The variants of the two libraries based on L36 and E79 showed large decreases in thermostability compared to WT. In contrast, the thermostability of the A39P and H99Y variants from the A39 and H99 libraries were slightly more thermostable that wild-type UDH, which the double mutant, A39P/H99Y, performed better. H234K showed the best thermostability and specific activity compared to other variants in the H234K library and also slightly outperformed single mutants from the other libraries. When these mutants were combined, the resulting double or triple mutants showed synergistic effects, improving thermostability still further; the triple mutant A39P/H99Y/H234K performed best (Fig. 3). To define the optimal temperature and $\mathrm{pH}$ for the most promising variants, the double mutants $\mathrm{H} 99 \mathrm{Y} / \mathrm{H} 234 \mathrm{~K}$ and the triple A39P/H99Y/H234K were assayed across a temperature range of $30-65{ }^{\circ} \mathrm{C}$ and a $\mathrm{pH}$ range of 5.0-9.0 (Fig. 4). These experiments showed the optimal temperature of the mutants to be $35^{\circ} \mathrm{C}$ (Fig. 4a) and the optimal pH to be 8.0 (Fig. 4b). 

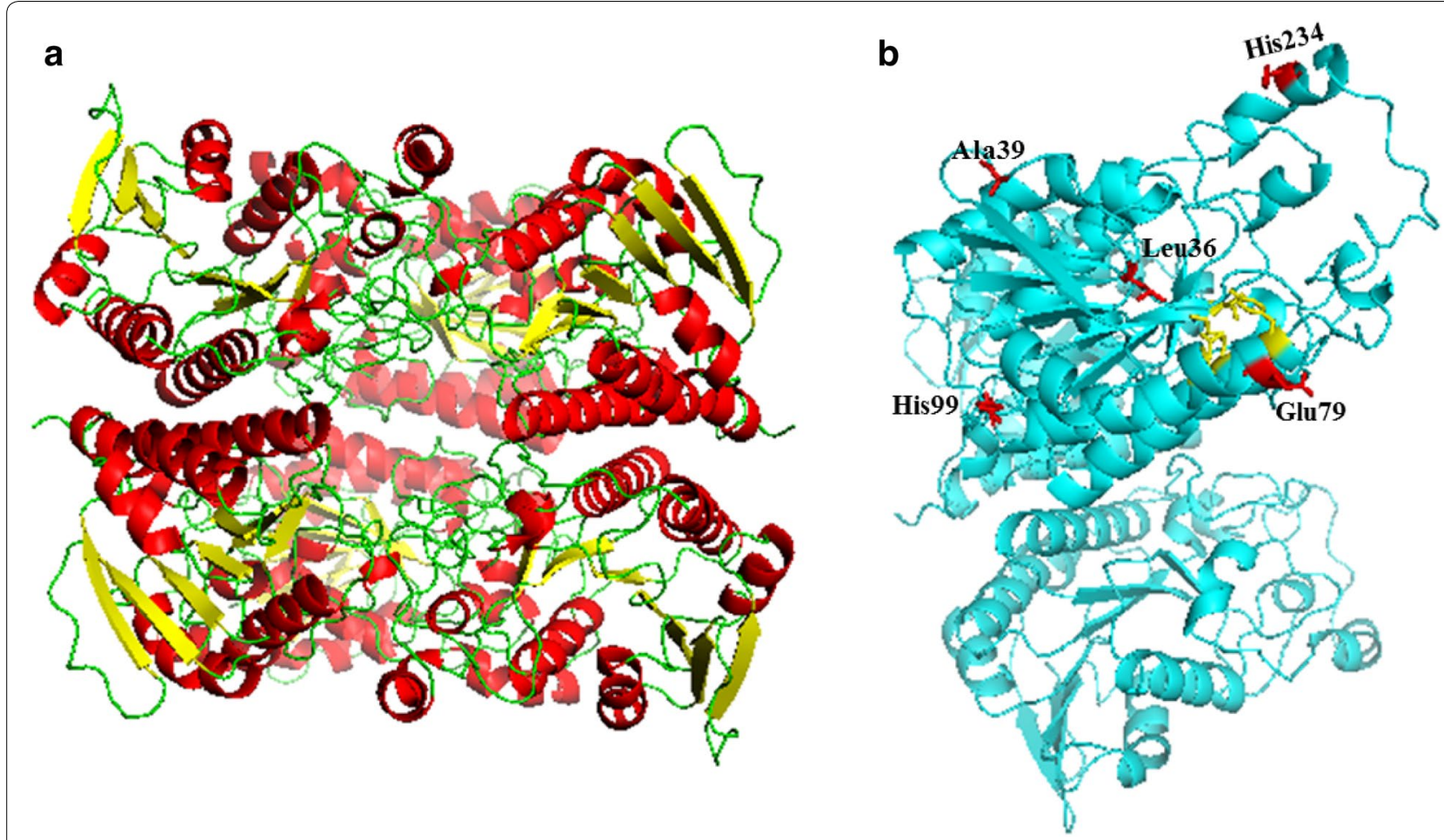

Fig. 2 Structural model of AtLBA4404 UDH. a Cartoon representation of the overall AtLBA4404 UDH structure. b The mutated amino acids are shown in red, the catalytic center in yellow (86Asn, 109Ser, 134Tyr, 138Lys)

\section{Stability assay}

In this study, the $\mathrm{T}_{50}^{10}$ value of the purified wild-type enzyme was $58{ }^{\circ} \mathrm{C}$, but the kinetic stability improved markedly for three double or triple variants (A39P/H99Y, A39P/H234K and A39P/H99Y/H234K), while improving slightly for the single mutants A39P, H99Y and H234K. Especially promising was the $\mathrm{T}_{50}^{10}$ value for $\mathrm{A} 39 \mathrm{P} / \mathrm{H} 99 \mathrm{Y} /$ $\mathrm{H} 234 \mathrm{~K}$, which increased to $63{ }^{\circ} \mathrm{C}$, a difference of $5{ }^{\circ} \mathrm{C}$ compared to wild-type (Table 2). We also determined the activity of the variant A39P/H99Y/H234K compared to wild-type UDH after incubation for various times at $58{ }^{\circ} \mathrm{C}$. The first-order kinetics of both enzymes was obtained by measuring residual activity at $59{ }^{\circ} \mathrm{C}$. As shown in Fig. 5, the activity of A39P/H99Y/H234K increased by more than $50 \%$ in the first minute compared to wild-type UDH, then dropped in the next two minutes. Over the next $60 \mathrm{~min}$, the activity fell to $53 \%$ of the initial activity, and then maintained $50 \%$ activity for another $60 \mathrm{~min}$ at $59^{\circ} \mathrm{C}$. Even after $400 \mathrm{~min}$ at $59^{\circ} \mathrm{C}$, the A39P/H99Y/H234K variant retained more than $25 \%$ of the initial activity. Hence, the $t_{1 / 2}$ of A39P/H99Y/H234K improved approximately 400 -fold compared to wild-type $\mathrm{UDH}$, from $18 \mathrm{~s}$ to $120 \mathrm{~min}$ at $59^{\circ} \mathrm{C}$. The specific activity of the variants also improved, with A39P/H99Y/H234K

Table 1 Kinetic parameters of UDH from wt and mutants toward substrate glucuronic acid

\begin{tabular}{|c|c|c|c|c|c|}
\hline Mutants & $k_{\text {cat }}\left(10^{2} \mathrm{~s}^{-1}\right)$ & $K_{m}(\mathrm{mM})$ & $k_{\mathrm{cat}} / K_{m}\left(10^{2} \mathrm{~s}^{-1} \mathrm{mM}^{-1}\right)$ & $\begin{array}{l}\text { Specific activity } \\
\left(\mathrm{U} \mathrm{mg}^{-1}\right)\end{array}$ & $\begin{array}{l}\text { Relative } \\
\text { activity } \\
(100 \%)\end{array}$ \\
\hline WT & $1.61 \pm 0.3$ & $0.20 \pm 0.06$ & 8.0 & $85 \pm 2.1$ & $100.0 \pm 3.2$ \\
\hline A39P & $1.92 \pm 0.5$ & $0.26 \pm 0.03$ & 7.3 & $88 \pm 3.1$ & $103.5 \pm 2.6$ \\
\hline H99Y & $1.79 \pm 0.4$ & $0.23 \pm 0.05$ & 7.7 & $93 \pm 4.1$ & $109.6 \pm 3.4$ \\
\hline H234K & $1.95 \pm 0.2$ & $0.24 \pm 0.03$ & 8.1 & $110 \pm 3.1$ & $129.4 \pm 2.9$ \\
\hline A39P/H99Y & $2.39 \pm 0.1$ & $0.20 \pm 0.04$ & 7.2 & $124 \pm 2.9$ & $146.8 \pm 3.2$ \\
\hline A39P/H234K & $2.95 \pm 0.4$ & $0.18 \pm 0.06$ & 8.4 & $140 \pm 3.6$ & $165.7 \pm 3.5$ \\
\hline H99Y/H234K & $3.18 \pm 0.5$ & $0.17 \pm 0.05$ & 8.6 & $149 \pm 1.9$ & $175.4 \pm 2.9$ \\
\hline A39P/H99Y/H234K & $3.8 \pm 0.7$ & $0.15 \pm 0.03$ & 9.1 & $210 \pm 3.0$ & $247.6 \pm 3.5$ \\
\hline
\end{tabular}




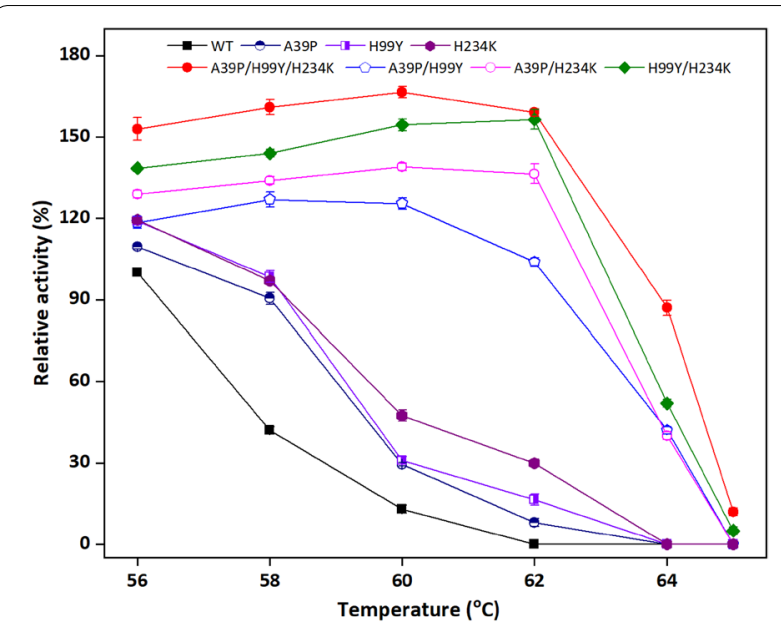

Fig. 3 Stability of wild-type UDH and all three variants, measured by the decrease in initial activity after 10 min incubation at the temperatures indicated. $100 \%$ activity is the activity of each enzyme incubated at optimum temperature for $30 \mathrm{~min}$. A39P/H99Y/H234K, A39P/H234K and H99Y/H234K showed heat activation profiles

showing a 2.5 -fold at $30{ }^{\circ} \mathrm{C}(210 \mathrm{U} / \mathrm{mg})$ compared to wild-type (Table 1 ).

\section{Bioconversion of GlcA with purified UDH}

The bioconversion of the substrate GlcA by UDH was carried out for over $200 \mathrm{~min}$ at $37{ }^{\circ} \mathrm{C}$ to determine the yield of GA obtained, which was assessed by NMR
(Additional file 1: Fig. S5), using the enzyme variants. The titer of GA was significantly higher for both the $\mathrm{H} 99 \mathrm{Y} / \mathrm{H} 234 \mathrm{~K}$ and $\mathrm{A} 39 \mathrm{PH} 99 \mathrm{Y} / \mathrm{H} 234 \mathrm{~K}$ variants in the first $90 \mathrm{~min}(p<0.01)$, then slowly continued to improve and still had not reached a maximum after $200 \mathrm{~min}$. The final titer of GA was $27 \mathrm{mM} \pm 0.05$ at $200 \mathrm{~min}$ for A39P/ $\mathrm{H} 99 \mathrm{Y} / \mathrm{H} 234$, and $24 \mathrm{mM} \pm 0.10$ at $200 \mathrm{~min}$ for $\mathrm{H} 99 \mathrm{Y} /$ H234. Wild-type, H99Y/H234K and A39P/H99Y/H234K UDH demonstrated GA yields of $70 \%, 80 \%$ and $90 \%$, respectively (Fig. 6).

\section{Discussion}

Compared with previous research, the UDH mutant produced in this study by rational evolution has both higher thermostability and improved activity (Table 3). After generating various single and combined mutations, we found that the best mutant $(\mathrm{A} 39 \mathrm{P} / \mathrm{H} 99 \mathrm{Y} / \mathrm{H} 234 \mathrm{~K})$ had a 400-fold improvement in half-life at $58^{\circ} \mathrm{C}$, higher kinetic stability $\left(\Delta \mathrm{T}_{50}^{30}=5^{\circ} \mathrm{C}\right)$ and 2.5 -fold higher specific activity at $30^{\circ} \mathrm{C}$ than wild-type UDH.

The sites chosen for mutagenesis were located near the catalytic center ( $<10 \AA$ distant) and had good exposure to solvent (default value $\geq 30$ ) (Eijsink et al. 2004; Kokkinidis et al. 2012; Wintrode et al. 2003). These positions (L36, A39, E79, H99, H234) were identified. In comparison with wild-type, H234K showed higher thermostability; while, A39P and H99Y were only slightly more thermostable. The triple mutant showed a greater improvement in thermostability than the sum of its three constituent
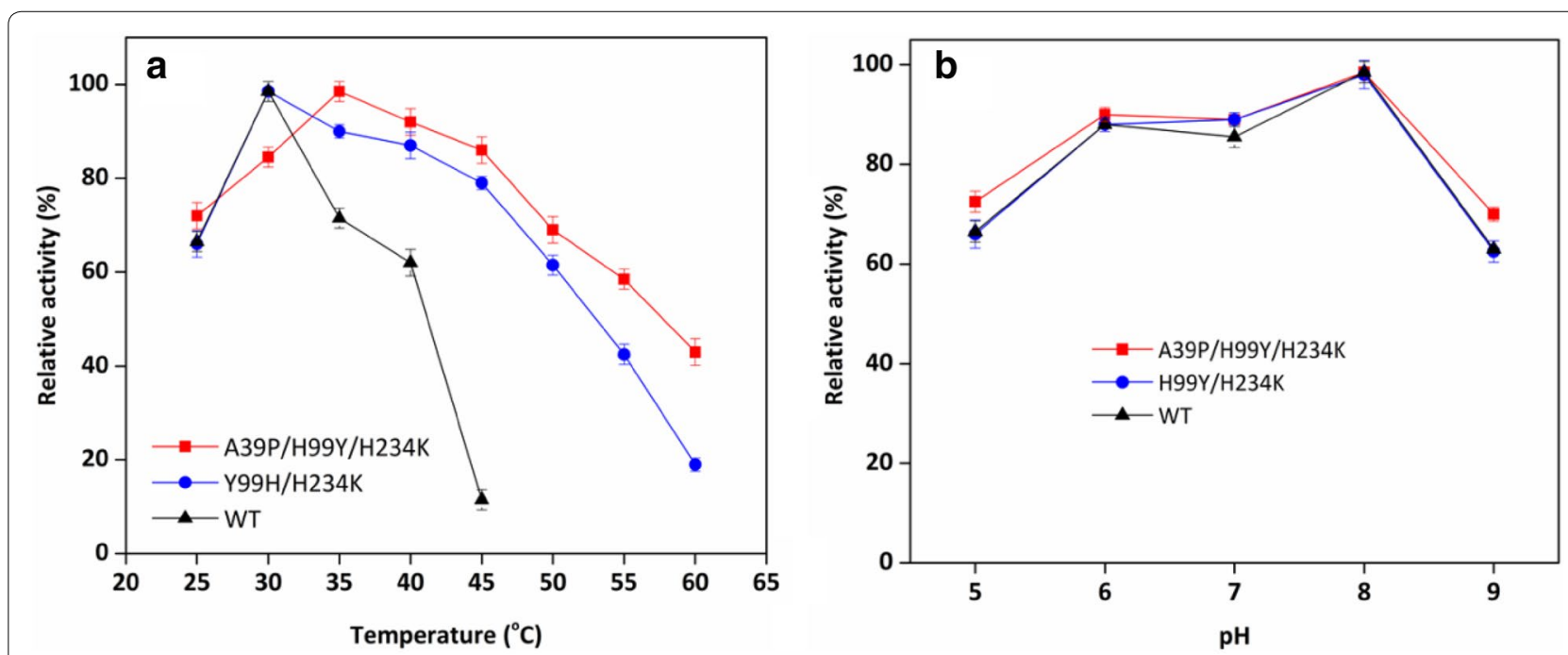

Fig. 4 Optimal temperature and pH values of UDH mutants. (a) Optimal temperature was determined in pH 8.0 buffer. (b) Optimal pH was determined at $37^{\circ} \mathrm{C}$ except for $\mathrm{H} 99 \mathrm{Y} / \mathrm{H} 234 \mathrm{~K}$ and wild-type UDH $\left(30^{\circ} \mathrm{C}\right)$ 
Table 2 Thermostability and activity parameters of wildtype and mutants of AtLBA 4404 UDH

\begin{tabular}{|c|c|c|c|c|}
\hline Enzyme & $\begin{array}{l}\text { Relative } \\
\text { activity } \\
\left(30^{\circ} \mathrm{C}\right)\end{array}$ & $\begin{array}{l}t_{1 / 2}(\min ) \\
\left(59^{\circ} \mathrm{C}\right)\end{array}$ & $\begin{array}{l}\text { Improvement } \\
\text { of } t_{1 / 2}\left(59^{\circ} \mathrm{C}\right)\end{array}$ & $\Delta T_{50}^{10}$ \\
\hline WT & $85 \pm 2.1$ & $0.30 \pm 0.02$ & 1 & 0 \\
\hline A39P & $88 \pm 3.1$ & $0.60 \pm 0.1$ & 1.8 & 0 \\
\hline H99Y & $93 \pm 4.1$ & $1.30 \pm 0.5$ & 4.3 & 2 \\
\hline $\mathrm{H} 234 \mathrm{~K}$ & $110 \pm 3.1$ & $5.10 \pm 1.1$ & 17 & 2.5 \\
\hline A39P/H99Y & $124 \pm 2.9$ & $1.10 \pm 0.5$ & 3.5 & 3 \\
\hline A39P/H234K & $140 \pm 3.6$ & $6.30 \pm 1.9$ & 21 & 3.5 \\
\hline H99Y/H234K & $149 \pm 1.9$ & $16.00 \pm 2.5$ & 53 & 4 \\
\hline $\begin{array}{c}\text { A39P/H99Y/ } \\
\text { H234K }\end{array}$ & $210 \pm 3.0$ & $120 \pm 3.5$ & 400 & 5 \\
\hline
\end{tabular}

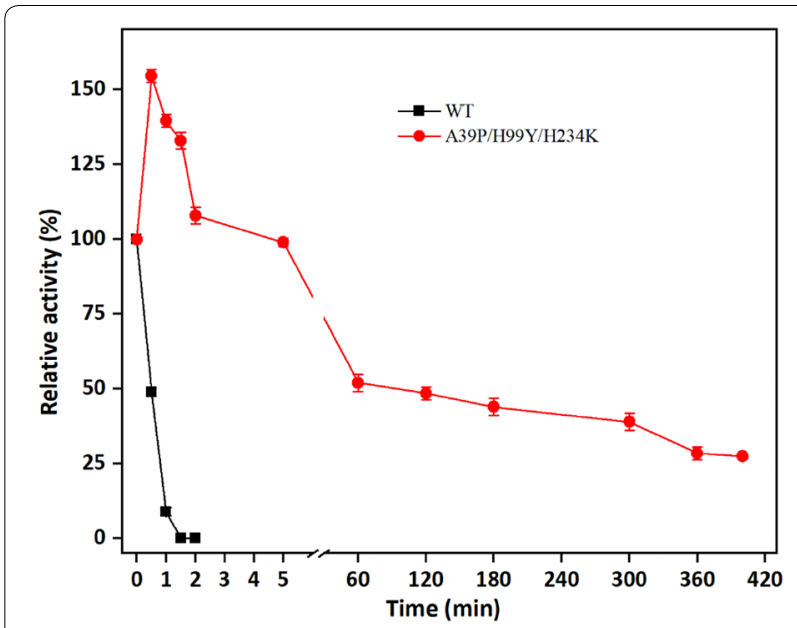

Fig. 5 Kinetic stability of the wild-type UDH and the triple mutant (A39P/H99Y/H234K) at $59^{\circ} \mathrm{C}$. Remaining activity was measured at $30^{\circ} \mathrm{C}$ and $37^{\circ} \mathrm{C}$ for the wild-type UDH and the triple mutant (A39P/ H99Y/H234K)

individual mutations, demonstrating a positive synergistic effect. This reflects similar observations in the literature (Istomin et al. 2010; Reetz et al. 2010; Reetz 2013).

The three mutations (A39P, H99Y and H234K) combined within our best variant UDH (A39P/H99Y/H234K) are all located on the surface of the enzyme. It is well known that mutations that increase the thermostability are often found in surface regions (Eijsink et al. 2004; Wintrode et al. 2003; Stellwagen and Wilgus 1978). The mechanisms underlying the effect of these three mutations on thermostability can be rationalized by analysis of the enzyme structure (Deng et al. 2014; Samuel et al. 2018). Thus, the A39P mutation is stabilizing because proline can disrupt alpha-helix and beta-sheet, but is less of a problem at the surface; on the other hand, it is more prevalent in the proteins of thermophilic organisms, and

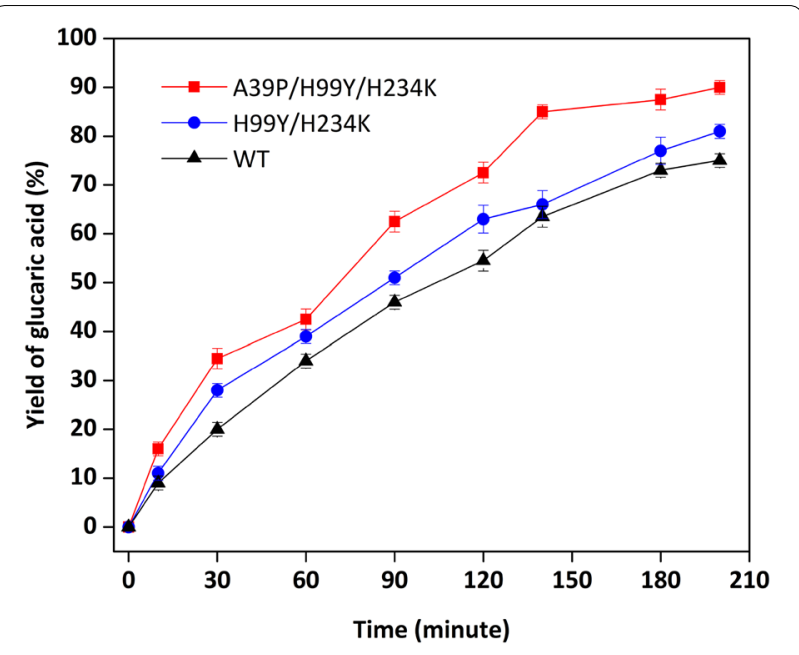

Fig. 6 Oxidative conversion of glucuronic acid to glucaric acid

lowers the conformational entropy (Wu et al. 2017; Ruller et al. 2010). Similarly, the tyrosine residue introduced in the H99Y mutant contains aromatic group, which can contribute to improve protein thermostability (Burley and Petsko 1985). For the H234K mutant, replacing histidine with lysine can enhance the formation of helices with a low cut-off, which could result in the improvement of thermostability (Wijma et al. 2013).

Additionally, increased thermostability, any engineered version of UDH would ideally also have higher catalytic activity to be of value to industry. However, directed evolution studies have suggested that these two characteristics, thermostability and activity, cannot both be optimized for an enzyme due to a stability-activity trade-off (Giver et al. 1998). Nevertheless, this trade-off has been challenged by protein engineering using genetic or chemical methods (Nguyen et al. 2017). Indeed, it has been suggested that a polyphosphate glucokinase (PPGK) mutant shows good compatibility between thermostability and activity after four rounds of directed evolution (Zhou et al. 2018). In our study, we found that both thermostability and activity showed a marked improvement in the A41P/ H101Y/H236K UDH mutant derived from AtLBA4404. Similarly, a previously reported triple variant derived from AtC58, A41P/H101Y/H236K showed significantly improved thermostability; however, this mutant showed no enhancement in activity (Roth et al. 2017). The reasons for this difference might be as follows: (a) although the UDH from $A$. tumefaciens LBA4404 is very similar to that from $A$. tumefaciens $\mathrm{C} 58$, it is not identical. As shown in Additional file 1: Fig. S1, the differences between A. tumefaciens LBA4404 UDH and A. tumefaciens C58 UDH are mainly on C terminus, 
Table 3 Comparison of enzymatic properties of characterization UDH

\begin{tabular}{|c|c|c|c|}
\hline Strain & Specific activity (U/mg) & Half lifetime & References \\
\hline A. tumefaciens C58 & $67\left(\mathrm{pH} 8.0,30^{\circ} \mathrm{C}\right)$ & $50 \min \left(\mathrm{pH} 8.0,37^{\circ} \mathrm{C}\right)$ & Istomin et al. (2010) \\
\hline P. putida KT2440 & $68\left(\mathrm{pH} 8.0,30^{\circ} \mathrm{C}\right)$ & $30 \min \left(\mathrm{pH} 8.0,37^{\circ} \mathrm{C}\right)$ & Deng et al. (2014) \\
\hline A. tumefaciens GV3101 & $73\left(\mathrm{pH} 8.0,30^{\circ} \mathrm{C}\right)$ & $55 \min \left(\mathrm{pH} 8.0,37^{\circ} \mathrm{C}\right)$ & This study \\
\hline A. tumefaciens EHA105 & $70\left(\mathrm{pH} 8.0,30^{\circ} \mathrm{C}\right)$ & $55 \min \left(\mathrm{pH} 8.0,37^{\circ} \mathrm{C}\right)$ & This study \\
\hline P. naphthalenivorans & $80\left(\mathrm{pH} 8.0,30^{\circ} \mathrm{C}\right)$ & $60 \min \left(\mathrm{pH} 8.0,37^{\circ} \mathrm{C}\right)$ & Kokkinidis et al. (2012) \\
\hline T. bispora DSM43833 & $95\left(\mathrm{pH} 7.0,50^{\circ} \mathrm{C}\right)$ & $60 \min \left(\mathrm{pH} 7.0,60^{\circ} \mathrm{C}\right)$ & Komari et al. (2010) \\
\hline A. tumefaciens LBA4404 & $86\left(\mathrm{pH} 8.0,30^{\circ} \mathrm{C}\right)$ & $<2 \min \left(\mathrm{pH} 8.0,59^{\circ} \mathrm{C}\right)$ & This study \\
\hline A. tumefaciens LBA4404 & $210\left(\mathrm{pH} 8.0,37^{\circ} \mathrm{C}\right)$ & $400 \min \left(\mathrm{pH} 8.0,59^{\circ} \mathrm{C}\right)$ & This study \\
\hline
\end{tabular}

which might be responsible for the different properties (Katoh et al. 2003; Li et al. 2018); (b) the A. tumefaciens LBA4404 used in our study is a model strain, and is often used in plant genetic transformation systems in the laboratory, which, to some extent, has led to the domestication of the strain, which might affect its genes and corresponding proteins (Aldemita and Hodges 1996; Komari et al. 2010). It is possible, therefore, that through the separate evolution and recombination of multiple independent characteristics, some rare mutations that improve both thermostability and activity at the same time could be identified under special conditions (Giver et al. 1998; Arnold et al. 2001).

\section{Conclusions}

In summary, we obtained a highly improved triple mutant (A39P/H99Y/H234K) of UDH, based on a homology model of AtLBA4404 UDH, by analysis of the catalytic center and subsequent surface engineering. The A39P/H99Y/H234K variant demonstrated a 400-fold better half-life time at $59{ }^{\circ} \mathrm{C}$, higher kinetic stability $\left(\Delta \mathrm{T}_{50}^{10}=5{ }^{\circ} \mathrm{C}\right)$ and 2.5 -fold higher specific activity at $30{ }^{\circ} \mathrm{C}$ than wild-type UDH. The simultaneously improved specific activity and thermostability of this variant provides a novel alternative for the industrial production of GA from GlcA.

\section{Supplementary information}

Supplementary information accompanies this paper at https://doi. org/10.1186/s40643-019-0267-3.

Additional file 1. Additional tables and figures.

\section{Abbreviations}

UDH: uronate dehydrogenase; E. coli: Escherichia coli; At: Agrobacterium tumefaciens; S. cerevisiae: Saccharomyces cerevisiae; Inol: myo-inositol-1-phosphate synthease; MIOX: myo-inositol oxygenase; LB: Lysogeny Broth; PCR: polymerase chain reaction; WT: wild type; IPTG: isopropyl $\beta$-D-1-thiogalactopyranoside; GA: glucaric acid; GlcA: glucuronic acid.

\section{Acknowledgements}

Not applicable.

\section{Authors' contributions}

HHS, FP, PX and XLW carried out the experiments. HHS wrote the draft manuscript. WYL, MHZ and JGY participated in the design of the study and revision of the manuscript. All authors read and approved the final manuscript.

\section{Funding}

This work was funded by the National Natural Science Foundation of China (21676104, 21878105), the National Key Research and Development Program of China (2018YFC1603400, 2018YFC1602100), and the Science and Technology Program of Guangzhou (201904010360) for partially funding this work.

Availability of data and materials

The data on which the conclusions are all presented in this paper.

Ethics approval and consent to participate

Not applicable.

Consent for publication

Not applicable.

\section{Competing interests}

The authors declare that they have no competing interests.

\section{Author details}

${ }^{1}$ Laboratory of Applied Biocatalysis, School of Food Science and Engineering, South China University of Technology, Guangzhou 510640, People's Republic of China. ${ }^{2}$ South China Institute of Collaborative Innovation, Xincheng Road, Dongguan 523808, People's Republic of China.

Received: 25 June 2019 Accepted: 28 Auqust 2019

Published online: 23 September 2019

\section{References}

Aldemita RR, Hodges TK (1996) Agrobacterium tumefaciens mediated transformation of japonica and indica rice varieties. Planta 199:612-617

Alponti JS, Fonseca-Maldonado R, Ward RJ (2016) Thermostabilization of Bacillus subtilis gh 11 xylanase by surface charge engineering. Int J Biol Macromol 87:522-528

Arnold FH, Wintrode PL, Miyazaki K, Gershenson A (2001) How enzymes adapt: lessons from directed evolution. Trends Biochem Sci 26:100-106

Bespalov VG, Aleksandrov VA (2012) Anticarcinogenic effect of potassium salts of glucaric and glucuronic acid in induced models of cervical and esophageal tumors. Vopr Onkol 58:537-540

Biasini M, Bienert S, Waterhouse A, Arnold K, Studer G, Schmidt T, Kiefer F, Cassarino TG, Bertoni M, Bordoli L, Schwede T (2014) Swiss-model: modelling protein tertiary and quaternary structure using evolutionary information. Nucleic Acids Res 42:W252-W258 
Blair JA, Rauh D, Kung, Yun CH, Fan QW, Rode H, Zhang C, Eck MJ, Weiss WA Shokat KM (2007) Structure-guided development of affinity probes for tyrosine kinases using chemical genetics. Nat Chem Biol 3:229-238

Burley SK, Petsko GA (1985) Aromatic-aromatic interaction: a mechanism of protein structure stabilization. Science 229:23-28

Deng Z, Yang H, Shin HD, Li J, Liu L (2014) Structure-based rational design and introduction of arginines on the surface of an alkaline a-amylase fromalkalimonas amylolyticafor improved thermostability. Appl Microbiol Biotechnol 98:8937-8945

Dwivedi C, Heck WJ, Downie AA, Larroya S, Webb TE (1990) Effect of calcium glucarate on $\beta$-glucuronidase activity and glucarate content of certain vegetables and fruits. Biochem Med Metab Biol 43:83-92

Eijsink VGH, Bjork A, Gaseidnes S, Sirevag R, Synstad B, Burg BVD, Vriend $G$ (2004) Rational engineering of enzyme stability. J Biotechnol 113:105-120

Etzl S, Lindner R, Nelson MD, Winkler A (2018) Structure-guided design and functional characterization of an artificial red light-regulated guanylate/adenylate cyclase for optogenetic applications. J Biol Chem 293:9078-9089

Giver L, Gershenson A, Feskgard P, Arnold FH (1998) Directed evolution of a thermostable esterase. Proc Natl Acad Sci USA 95:12809-12813

Hoffmann F, Sotriffer C, Evers A, Xiong GM, Maser (2007) Understanding oligomerization in 3alpha-hydroxysteroid dehydrogenase/carbonyl reductase from Comamonas testosteroni: an in silico approach and evidence for an active protein. J Biotechnol 129:131-139

Istomin A, Gromiha MO, Jacobs D, Livesay D (2010) New insight into longrange nonadditivity within protein double-mutant cycles. Proteins 70:915-924

Katoh R, Nagata S, Misono H (2003) Cloning and sequencing of the leucine dehydrogenase gene form Bacillus sphaericus IFO3525 and importance of the C-terminal region for the enzyme activity. J Mol Catal B Enzym 23:239-247

Kokkinidis M, Glykos NM, Fadouloglou VE (2012) Protein flexibility and enzymatic catalysis. Adv Protein Chem Struct Biol 87:181-218

Komari T, Hiei Y, Saito Y, Murai N, Kumashiro T (2010) Vectors carrying two separate T-DNAs for co-transformation of higher plants mediated by Agrobacterium tumefaciens and segregation of transformants free from selection markers. Plant J 10:165-174

Kruger N (1988) The bradford method for protein quantitation. Methods Mol Biol 32:9-15

Li YX, Xue YM, Cao ZG, Zhou T, Alnadari F (2018) Characterization of a uronate dehydrogenase from Thermobispora bispora for production of glucaric acid from hemicellulose substrate. World J Microbiol Biotechnol 34:102

Moon TS, Yoon SH, Lanza AM, Roy-mayhew JD, Prather KL (2009) Enhancing production of glucaric acid from a synthetic pathway in recombinant escherichia coli. Appl Environ Microbiol 75:589-595

Morton DW, Kiely DE (2000) Evaluation of the film and adhesive properties of some block copolymer polyhydroxypolyamides from esterified aldaric acids and diamines. J Appl Polym Sci 77:3085-3092

Nguyen V, Wilson C, Hoemberger M, Stiller JB, Agafonov RV, Kutter S, Theobald DL, Kern D (2017) Evolutionary drivers of thermoadaptation in enzyme catalysis. Science 355:289-294

Parkkinen T, Boer H, Janis J, Andberg M, Penttila M, Koivula A, Rouvinen J (2011) Crystal structure of uronate dehydrogenase from agrobacterium tumefaciens. J Biol Chem 286(31):27294-27300

Pick A, Schmid J, Sieber V (2015) Characterization of uronate dehydrogenases catalysing the initial step in an oxidative pathway. Microb Biotechnol 8:633-643

Reetz MT (2013) The importance of additive and non-additive mutational effects in protein engineering. Angew Chem Int Ed 52:2658-2666

Reetz MT, Soni P, Acevedo JP, Sanchis J (2010) Creation of an amino acid network of structurally coupled residues in the directed evolution of a thermostable enzyme. Angew Chem Int Ed 48:8268-8272

Roth T, Beer B, André P, Sieber V (2017) Thermostabilization of the uronate dehydrogenase from Agrobacterium tumefaciens by semi-rational design. AMB Express 7:103

Ruller R, Deliberto L, Ward R (2010) Thermostable variants of the recombinant xylanase A from Bacillus subtilis produced by directed evolution show reduced heat capacity changes. Proteins 70:1280-1293
Samuel S, Jörg C, Volker S (2018) Structure-guided engineering of a-keto acid decarboxylase for the production of higher alcohols at elevated temperature. Chemsuschem 11:3335-3344

Stellwagen E, Wilgus H (1978) Relationship of protein thermostability to accessible surface area. Nat 275:342-343

Sutiono S, Carsten J, Sieber V (2018) Structure-Guided Engineering of a-Keto Acid Decarboxylase for the production of higher alcohols at elevated temperature. ChemSusChem 11(18):3335-3344

Tanner JJ, Hecht RM, Krause KL (1996) Determinants of enzyme thermostability observed in the molecular structure of thermusaquaticusd-glyceraldehyde-3-phosphate dehydrogenase at $2.5 \AA$ resolution. Biochem 35:2597-2609

Thomas JL, Mason Jl, Brandt S, Spencer BR, Norris W (2002) Structure/function relationships responsible for the kinetic differences between human type 1 and type 23 beta-hydroxysteroid dehydrogenase and for the catalysis of the type 1 activity. J Biol Chem 277:42795-42801

Wagner G, Hollmann S (1976) Uronic acid dehydrogenase from Pseudomonas syringae. J Biochem 61:589-596

Wagschal K, Jordan DB, Lee CC, Younger A, Braker JD, Chan VJ (2015) Biochemical characterization of uronate dehydrogenases from three Pseudomonads, Chromohalobacter salixigens, and Polaromonas naphthalenivorans. Enzyme Microb Technol 69:62-68

Walaszek Z (1990) Potential use of D-glucaric acid derivatives in cancer prevention. Cancer Lett 54(1-2):1-8

Werpy TA, Holladay JE (2004) White JF (2004) Top value added chemicals from biomass: I. Results of screening for potential candidates from sugars and synthesis gas. Synthetic Fuels 1:263-275

Wijma HJ, Floor RJ, Janssen DB (2013) Structure- and sequence-analysis inspired engineering of proteins for enhanced thermostability. Curr Opin Struct Biol 23:588-594

Wintrode PL, Zhang D, Vaidehi N, Arnold FH, lii WAG (2003) Protein dynamics in a family of laboratory evolved thermophilic enzymes. J Mol Biol 327:745-757

Wu ZY, Deng WF, Tong YP, Liao Q, Xin DM, Yu HS, Feng J, Tang LX (2017) Exploring the thermostable properties of halohydrin dehalogenase from Agrobacterium radiobacter AD1 by a combinatorial directed evolution strategy. Appl Microbiol Biotechnol 101:3201-3211

Yang DF, Wei YT, Huang RB (2007) Computer-aided design of the stability of pyruvate formate-lyase from Escherichia coli by site-directed mutagenesis. Biosci Biotechnol Biochem 71:746-753

Yoon SH, Moon TS, Iranpour P, Lanza AM, Prather KJ (2009) Cloning and characterization of uronate dehydrogenases from two Pseudomonads and Agrobacterium tumefaciens strain c58. J Biotechnol 191:1565-1573

Zajic JE (1959) Hexuronic dehydrogenase of Agrobacterium tumefaciens. J Bacteriol 78:734-735

Zhang XF, Yang GY, Zhang Y, Xie Y, Withers SG, Feng Y (2016) A general and efficient strategy for generating the stable enzymes. Sci Rep 6:33797

Zhou W, Huang R, Zhu Z, Zhang Y (2018) Coevolution of both thermostability and activity of polyphosphate glucokinase from Thermobifida fusca YX. Appl Environ Microbiol 84:e01224

Zhu QQ, He WH, Kong XD, Fan LQ, Zhao J, Li SX, Xu JH (2014) Heterologous overexpression of vigna radiata, epoxide hydrolase in escherichia coli, and its catalytic performance in enantioconvergent hydrolysis of p-nitrostyrene oxide into (r)-p-nitrophenyl glycol. Appl Microbiol Biotechnol 98:207-218

Zółtaszek R, Hanausek M, Kiliańska ZM, Walaszek Z (2008) The biological role of D-glucaric acid and its derivatives: potential use in medicine. Postepy Hig Dosw 62:451-642

\section{Publisher's Note}

Springer Nature remains neutral with regard to jurisdictional claims in published maps and institutional affiliations. 